\title{
Neodymium isotopes do fractionate in magmatic environments
}

\author{
A.O. Kalashnikov*, P.A. Serov, J.A. Mikhailova, V.N. Yakovenchuk \\ Geological Institute, Kola Science Centre, Russian Academy of Sciences, Russia \\ *Corresponding author e-mail: kalashnikov@geoksc.apatity.ru
}

Summary We have revealed that $\varepsilon N d(T)$ changes from positive to negative near magmatic contacts, in the gabbro-norite Nyud and the peralkaline Lovozero massifs (NW Russia). We suppose that these reversions are caused by fractionation of neodymium isotopes by thermal diffusion near the contacts.

\section{Introduction and background to current research}

Recently, the fractionation of isotopes of various elements has been reported, but not for neodymium. For example, fractionation of isotopes of lithium (Marks et al. 2007), oxygen (Baumgartner and Valley 2001), magnesium (Teng et al. 2011), silicon (Savage et al. 2011) and iron (Schuessler et al. 2009) are used as geochemical tools. Fractionation of strontium isotopes is mentioned, too (Morse 1983). Obviously, the lighter an element, the more its isotopes mass difference, the easier their fractionation. For example, mass difference of ${ }^{7} \mathrm{Li}-{ }^{6} \mathrm{Li}$ is an order of magnitude greater, and ${ }^{57} \mathrm{Fe}-{ }^{56} \mathrm{Fe}$ is 2.5 times greater than that of ${ }^{144} \mathrm{Nd}-{ }^{143} \mathrm{Nd}$. So, it is not expected that $\mathrm{Nd}$ isotopes fractionate in magmatic-postmagmatic processes.

We investigate the Lovozero layered peralkaline massif (the Kola Peninsula, NW Russia). The massif consists of two complexes: the Layered (bottom) and the Eudialyte (top) complexes. The Layered complex is a stack of 'rhythms' (layered lithounits) (Fig. 1a). Each rhythm usually consists of a sequence of alkaline rocks (from top to bottom): malignite, foyaite, and urtite (Fig. 1b) (Gerasimovsky et al. 1966; Busen and Sakharov 1972). There are loparite enrichment on borders between the rhythms, sometimes up to economic concentration (so called the Loparite Horizons).
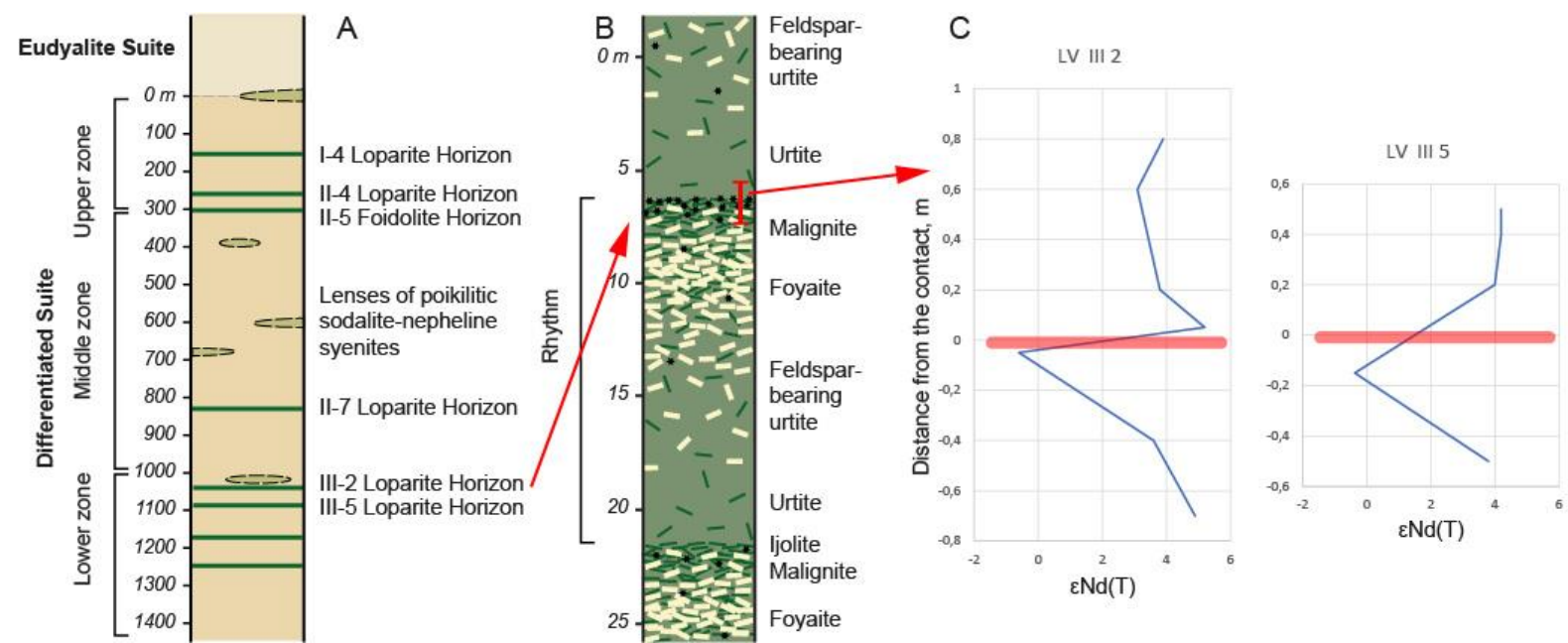

Figure 1. The Lovozero peralkaline massif: a - scheme of magmatic stratigraphy of the Layered Complex of the Lovozero massif; $b$ - a general structure of a 'rhythm' (layered lithounit) of the Layered Complex ((Gerasimovsky et al. 1966; Busen and Sakharov 1972; Kalashnikov et al. 2016); c - variations of $\varepsilon \mathrm{Nd}(\mathrm{T})$ along the transections across the Loparite Horizons LV-III-2 and LV-III-5. T $=362 \mathrm{Ma}$ (Kramm et al. 1993). 


\section{Results}

We sampled two transections across the Loparite Horizons III-2 and III-5 (studied earlier by G.Yu. Ivanyuk, V.N. Yakovenchuk and Ya.A. Pakhomovsky (Pakhomovsky et al. 2014; Ivanyuk et al. 2015)) and performed $\mathrm{Sm}-\mathrm{Nd}$ isotopic analyses. On average, $\varepsilon \mathrm{Nd}$ for the Lovozero massif is positive (Kramm and Kogarko 1994). However, in these transections, $\varepsilon N d$ becomes suddenly negative on the contacts of rhythms, in the loparite horizons (Fig. 2c).

To exclude an artifact and randomness, we performed a similar investigation in another pluton, the Nyud gabbro-norite massif (Murmansk Region, NW Rusia). There is a so-called Critical Horizon with sulphide enrichment within the massif. We sampled two transections across its bottom contact (Fig. 2a). Surprisingly, $\varepsilon N d$ becomes negative at the contact (Fig. 2b), again! What is a cause of this behaviour of neodymium isotopes?
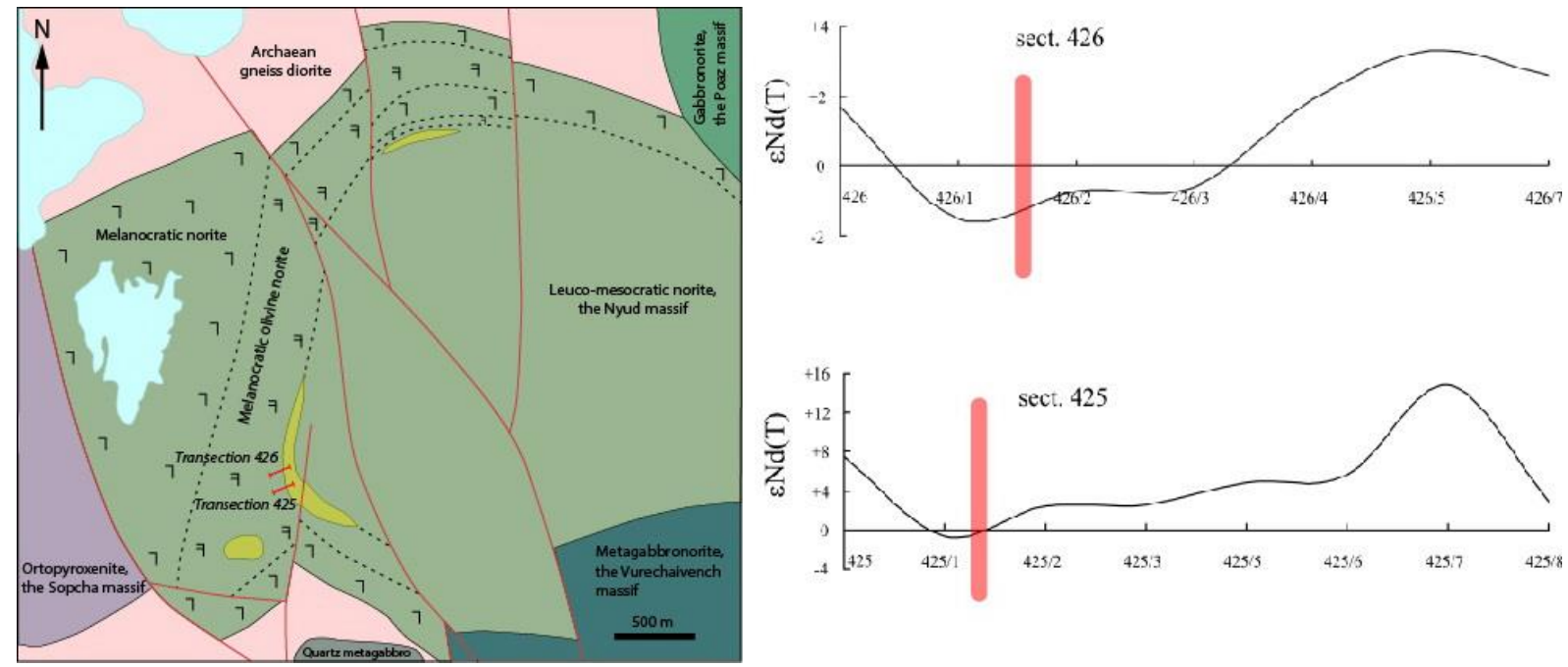

Figure 2. The Nyud gabbro-norite massif: a - a geological scheme, after (Chashchin et al. 2016); red lines are transections showed in Fig. $2 b ; b$ - variations of $\varepsilon N d(T)$ along the transections across the bottom contact (the red lines) of the Critical Horizon. $\mathrm{T}=2500 \mathrm{Ma}$ (Chashchin et al. 2016).

\section{Discussion and conclusions}

According to Lundstrom and colleagues, there is strong fractionation of elements (Fe, $\mathrm{Ti}, \mathrm{Mg}$, $\mathrm{Ca}, \mathrm{Na}, \mathrm{Al}, \mathrm{K}, \mathrm{Si}$ ) and isotopes of $\mathrm{Mg}$ and $\mathrm{Fe}$ along the thermal gradient (Huang et al. 2009), and they concluded that the thermal diffusion is a key cause of the fractionation (Huang et al. 2009; Lacks et al. 2012; Lundstrom 2016).

There is a point of view that large plutons were not crystallized from 'big magmatic tank', but formed as amalgamated small intrusions (Bartley et al. 2006; Annen et al. 2015). We believe that the Lovozero rhythms are sills emplaced sequentially (Féménias et al. 2005; Mikhailova et al. 2021), i.e. the Lovozero is an amalgamated pluton. So, there was a rather large thermal gradient on the contacts of "new" and "old" sills. It caused the thermal diffusion and probably fractionation of neodymium isotopes. Similar situation could take place in the Nyud pluton, if the Critical Horizon is a later sill emplaced between melanocratic olivine norite and leuco-mesocratic norite.

So, we have drawn the following conclusions. 1. We have found that $\varepsilon \mathrm{Nd}(\mathrm{T})$ changes from positive to negative on magmatic contacts within two layered plutons, the Lovozero and the Nyud. 2. We have supposed that these reversions are caused by fractionation of neodymium isotopes by thermal diffusion near the contacts. 3. If so, the variation of $\varepsilon \mathrm{Nd}(\mathrm{T})$ can be a tool for decomposition of amalgamated plutons. 


\section{Acknowledgements}

The investigation was funded by the Russian Science Foundation, project no. 21-47-09010 (isotopic analyses) and by the Ministry of Science and Higher Education of the Russian Federation, project no. 0226-2019-0051 (field works).

\section{References:}

Annen C, Blundy JD, Leuthold J, Sparks RSJ (2015) Construction and evolution of igneous bodies: Towards an integrated perspective of crustal magmatism. Lithos 230:206-221. https://doi.org/10.1016/j.lithos.2015.05.008

Bartley JM, Coleman DS, Glazner AF (2006) Incremental pluton emplacement by magmatic crack-seal. Trans R Soc Edinb Earth Sci 97:383-396. https://doi.org/10.1017/S0263593300001528

Baumgartner LP, Valley JW (2001) Stable Isotope Transport and Contact Metamorphic Fluid Flow. Rev Mineral Geochemistry 43:415-467. https://doi.org/10.2138/gsrmg.43.1.415

Busen IV, Sakharov AS (1972) Petrology of the Lovozero peralkaline massif. Nauka, Leningrad.

Chashchin V V., Bayanova TB, Mitrofanov FP, Serov PA (2016) Low-Sulfide PGE ores in paleoproterozoic Monchegorsk pluton and massifs of its southern framing, Kola Peninsula, Russia: Geological characteristic and isotopic geochronological evidence of polychronous ore-magmatic systems. Geol Ore Depos 58:3757. https://doi.org/10.1134/S1075701516010025

Féménias O, Coussaert N, Brassinnes S, Demaiffe D (2005) Emplacement processes and cooling history of layered cyclic unit II-7 from the Lovozero alkaline massif (Kola Peninsula, Russia). Lithos 83:371-393.

Gerasimovsky VI, Volkov VP, Kogarko LN, et al (1966) Geochemistry of the Lovozero peralkaline massif. Nauka, Moskow.

Huang F, Lundstrom CC, Glessner J, et al (2009) Chemical and isotopic fractionation of wet andesite in a temperature gradient: Experiments and models suggesting a new mechanism of magma differentiation. Geochim Cosmochim Acta 73:729-749. https://doi.org/10.1016/j.gca.2008.11.012

Ivanyuk GY, Pakhomovsky YA, Yakovenchuk VN (2015) Eudialyte-group minerals in rocks of Lovozero layered complex at Mt. Karnasurt and Mt. Kedykvyrpakhk. Geol Ore Depos 57:600-613. https://doi.org/10.1134/S1075701515070053

Kalashnikov AO, Konopleva NG, Pakhomovsky YA, Ivanyuk GY (2016) Rare Earth Deposits of the Murmansk Region, Russia-A Review. Econ Geol 111:1529-1559. https://doi.org/10.2113/econgeo.111.7.1529

Kramm U, Kogarko LN (1994) Nd and Sr isotope signatures of the Khibina and Lovozero agpaitic centres, Kola Alkaline province, Russia. Lithos 32:225-242. https://doi.org/10.1016/0024-4937(94)90041-8

Kramm U, Kogarko LN, Kononova VA, Vartiainen H (1993) The Kola Alkaline Province of the CIS and Finland: Precise $\mathrm{Rb}-\mathrm{Sr}$ ages define 380-360 Ma age range for all magmatism. Lithos 30:33-44.

Lacks DJ, Goel G, Bopp CJ, et al (2012) Isotope Fractionation by Thermal Diffusion in Silicate Melts. Phys Rev Lett 108:065901. https://doi.org/10.1103/PhysRevLett.108.065901

Lundstrom CC (2016) The role of thermal migration and low-temperature melt in granitoid formation: Can granite form without rhyolitic melt? Int Geol Rev 58:371-388. https://doi.org/10.1080/00206814.2015.1092098

Marks MAW, Rudnick RL, McCammon C, et al (2007) Arrested kinetic Li isotope fractionation at the margin of the Ilímaussaq complex, South Greenland: Evidence for open-system processes during final cooling of peralkaline igneous rocks. Chem Geol 246:207-230. https://doi.org/10.1016/j.chemgeo.2007.10.001

Mikhailova JA, Pakhomovsky YA, Kalashnikov AO, Yakovenchuk VN (2021) Formation of layering of the Lovozero peralkaline intrusion (Kola Peninsula, Russia): new data. In: Groshev NY (ed) ARLIN - Online Workshop 1. KOLARCTIC, Apatity, pp 24-27

Morse SA (1983) Strontium Isotope Fractionation in the Kiglapait Intrusion. Science (80- ) 220:193-195. https://doi.org/10.1126/science.220.4593.193

Pakhomovsky Y a., Ivanyuk GY, Yakovenchuk VN (2014) Loparite-(Ce) in rocks of the Lovozero layered complex at Mt. Karnasurt and Mt. Kedykvyrpakhk. Geol Ore Depos 56:685-698. https://doi.org/10.1134/S1075701514080054

Savage PS, Georg RB, Williams HM, et al (2011) Silicon isotope fractionation during magmatic differentiation. Geochim Cosmochim Acta 75:6124-6139. https://doi.org/10.1016/j.gca.2011.07.043

Schuessler JA, Schoenberg R, Sigmarsson O (2009) Iron and lithium isotope systematics of the Hekla volcano, Iceland - Evidence for Fe isotope fractionation during magma differentiation. Chem Geol 258:78-91. https://doi.org/10.1016/j.chemgeo.2008.06.021

Teng F-Z, Dauphas N, Helz RT, et al (2011) Diffusion-driven magnesium and iron isotope fractionation in Hawaiian olivine. Earth Planet Sci Lett 308:317-324. https://doi.org/10.1016/j.eps1.2011.06.003 